\title{
Molecular characterization of mycobacteria isolated from seals
}

1 Instituto de Biotecnología, CICV/INTA, Buenos Aires, Argentina

2 Departamento de Micobacterias, DILAB SENASA, C. C. 77 Morón (1708), Buenos Aires, Argentina

3 Fundación Mundo Marino, San Clemente del Tuyú Argentina

4 Laboratorio de Tuberculosis de la Dirección de Laboratorios Veterinarios (DILAVE) 'Miguel C. Rubino', Montevideo, Uruguay

5 Departamento de Microbiología, Salud Pública y Medicina Preventiva, Facultad de Medicina, Universidad de Zaragoza, Zaragoza, Spain

\author{
M. J. Zumárraga, ${ }^{1}$ A. Bernardelli, ${ }^{2}$ R. Bastida, ${ }^{3}$ V. Quse, ${ }^{3}$ J. Loureiro, ${ }^{3}$ \\ A. Cataldi, ${ }^{1}$ F. Bigi, ${ }^{1}$ A. Alito, ${ }^{1}$ M. Castro Ramos, ${ }^{4}$ S. Samper, ${ }^{5}$ I. Otal, ${ }^{5}$ \\ C. Martin ${ }^{5}$ and M. I. Romano ${ }^{1}$
}

Author for correspondence: M. I. Romano. Tel: +54 1621 1447. Fax: +54 14812975. e-mail:mromano@cicv.inta.gov.ar

\begin{abstract}
Tuberculosis (TB) was diagnosed in 10 seals from three species (Arctocephalus australis, Arctocephalus tropicalis and Otaria flavescens) found in South America. The mycobacteria isolated from these cases belonged to the Mycobacterium tuberculosis complex, as determined by RFLP using an IS6110 probe, spoligotyping, analysis of the 16S rRNA gene sequence and by PCRrestriction analysis of hsp65. Polymorphisms in gyrA, katG, oxyR and pncA were investigated in some of the isolates, as well as the presence of the MPB70 antigen. The insertion sequence IS6110 was present in three to seven copies in the genome of the mycobacteria isolated from seals. Using the IS6110 probe, six patterns (designated A, B, C, D, E and F) were identified from 10 different isolates. Patterns $A$ and $B$ were found for the mycobacteria isolated from two and four seals, respectively, indicating an epidemiological relationship between isolates grouped according to their IS6110 RFLP. The mycobacteria isolated from seals shared the majority of their IS6110 DNAcontaining restriction fragments, and nine isolates had an identical spoligotype; only one isolate showed a minor difference in its spoligotype. In addition, none of these spoligotypes were found in other $M$. tuberculosis complex strains. These results suggest that the isolates from seals constitute a unique group of closely related strains. The mycobacteria isolated from seals showed polymorphisms at gyrA codon 95 and katG codon 463, as do group 1 $M$. tuberculosis, and $M$. bovis. Group 1 mycobacteria are associated with cluster cases. The spoligotypes found in the mycobacteria isolated from seals lack spacers 39-43, as does $M$. bovis, but the MPB70 antigen, which is highly expressed in $M$. bovis and minimally expressed in $M$. tuberculosis, was not detected in these mycobacteria. The mycobacteria isolated from seals also showed oxyR and pncA polymorphisms specific to $M$. tuberculosis. In conclusion, the mycobacteria that cause TB in seals in the South-Western Atlantic are a related group, and based on the combination of genetic characteristics, belong to a unique genotypic group within the M. tuberculosis complex.
\end{abstract}

Keywords: tuberculosis, Mycobacterium tuberculosis complex, spoligotyping, RFLP

\section{INTRODUCTION}

During the period 1986-92 the first cases of tuberculosis (TB) in wild seals were registered on the Australian Pacific coast (Cousins et al., 1990; Forshaw \& Phelps,

Abbreviations: DR, direct repeat; PZA, pyrazinamide; Pzase, pyrazinamidase; TB, tuberculosis.
1991; Cousins et al., 1993; Thompson et al., 1993) and the South-Western Atlantic coast (Bernardelli et al., 1993, 1996; Romano et al., 1995). These isolates were characterized as belonging to the Mycobacterium tuberculosis complex, and several genetic markers were used to confirm the relatedness between the mycobacteria isolated from seals (Cousins et al., 1993; Romano et al., 1995). The most widely used genetic 
marker for molecular epidemiology of TB is the insertion sequence IS6110 (Hermans et al., 1992; van Soolingen et al., 1993; Romano et al., 1996; Samper et al., 1997), which is a mobile genetic element present exclusively in the genome of members of the $M$. tuberculosis complex (M. tuberculosis, M. bovis, M. bovis BCG, $M$. africanum and M. microti). M. bovis isolates have often been found to harbour only a single copy of IS6110 (Romano et al., 1996), while mycobacteria isolated from seals, as well as M. tuberculosis, show several copies of this element (Cousins et al., 1993; Romano et al., 1995; Bernardelli et al., 1996).

A new technique called spoligotyping was designed as a tool for molecular epidemiology of the M. tuberculosis complex (Kamerbeek et al., 1997). The method is based on the in vitro amplification of the DNA sequence of the highly polymorphic direct repeat (DR) locus in the chromosome of members of the M. tuberculosis complex. This region flanks an IS6110 copy, and has a characteristic organization, with conserved 36 bp DR sequences interspersed with variable spacers (Hermans et al., 1991). The polymorphism is due to these spacers, which are variable in length, sequence and number. The spoligotyping technique detects the spacers present in the strains, and allows each to be characterized by its spacer content (Kamerbeek et al., 1997). Spoligotyping has been used to type isolates of M. tuberculosis (Goguet de la Salmonière et al., 1997) and M. bovis (Aranaz et al., 1996; Blázquez et al., 1997; Cousins et al., 1998; Zumárraga et al., 1999).

Currently, strains of M. bovis and M. tuberculosis are distinguished by several biochemical parameters, including niacin accumulation, pyrazinamide (PZA) susceptibility, pyrazinamidase (Pzase) activity, nitrate reduction and thiophenecarboxylic acid hydrazide susceptibility (Collins et al., 1985). An immunological method for differentiating between $M$. bovis and $M$. tuberculosis based on detection of the protein antigen MPB70 in M. bovis has been reported (Harboe \& Nagai, 1984), but its use and reliability are limited because this protein is also present in M. tuberculosis. This protein is highly expressed in M. bovis and minimally expressed in M. tuberculosis (Harboe \& Nagai, 1984). The mtp40 gene, considered to be present in M. tuberculosis but absent in $M$. bovis, was used to differentiate $M$. tuberculosis from M. bovis (Del Portillo et al., 1991). However, this method has recently been invalidated, as the gene has been shown not to be present in all $M$. tuberculosis strains, and not absent in all M. bovis strains (Weil et al., 1996). In many mycobacteria, $16 \mathrm{~S}$ rRNA and the heat-shock protein gene ( $h s p 65$ ) contain variable sequences that allow mycobacterial differentiation at the species level. However, within the $M$. tuberculosis complex, these genes are not variable. (Kirschner et al., 1993; Telenti et al., 1993). M. tuberculosis complex organisms have multiple mutations in the $\operatorname{oxyR}$ gene, a homologue of the extensively studied central regulator of peroxide stress response in enteric bacteria (Deretic et al., 1997). Because oxyR in $M$. tuberculosis complex isolates probably does not encode a functional protein, it is referred to as a pseudogene. In $M$. bovis the $o x y R$ pseudogene has an adenine residue at nucleotide 285 , while the remaining M. tuberculosis complex strains have a guanine residue (Sreevatsan et al., 1996). In addition, the Pzase gene $(p n c A)$ has a guanine instead of a cytosine residue at nucleotide position 169 in M. bovis. This results in production of an inactive Pzase, thus conferring resistance to PZA in these strains (Scorpio \& Zhang, 1996). Therefore, polymorphisms in the $o x y R$ and pncA genes allow differentiation of $M$. bovis from the other mycobacteria of the complex.

M. tuberculosis can be assigned to one of three distinct genotypic groups, based on the combinations of polymorphisms at the genes encoding catalase-peroxidase (katG) and the A subunit of gyrase $(g y r A)$. M. tuberculosis group 1 has the allele combination katG codon 463 CTG (Leu) and gyrA codon 95 ACC (Thr); group 2 has $k a t G$ codon 463 CGG (Arg) and gyrA codon 95 ACC (Thr); group 3 has kat $G$ codon 463 CGG (Arg) and gyrA codon 95 AGC (Ser). All isolates of M. bovis, M. microti and M. africanum studied have the combination of polymorphisms of M. tuberculosis group 1 . The isolates of M. tuberculosis grouped in clusters were mainly of genotypic groups 1 and 2 (Sreevatsan et al., 1997).

The aim of this study was to evaluate the epidemiological relationship and genetic characteristics of the mycobacteria that cause TB in seals in South America.

\section{METHODS}

Mycobacterial isolates. A total of 10 cases of TB in seals, with bacteriological confirmation, were included in this study. Nine of these cases (Table 1, cases 2 to 10) were from wild seals (the South American fur seal Arctocephalus australis and Subantarctic fur seal Arctocephalus tropicalis) found on the Argentine coast during the period 1991-96. These animals were caught for medical treatment at the Rehabilitation Centre of the Foundation Marine World (San Clemente del Tuyú, Argentina). One case (Table 1, case 1) was from an outbreak of TB occurring in 1987 in captive South American sea lions (Otaria flavescens) at the Montevideo Zoo (Uruguay) (Castro Ramos et al., 1998). Only one isolate from this outbreak was included in the present study.

Samples obtained from necropsies were processed by the Petroff decontamination method, and inoculated on Löwenstein-Jensen and Stonebrink media.

The mycobacteria isolated from seals were susceptible to PZA, isoniazid, streptomycin, rifampicin, ethambutol and thiophene-2-carboxylic acid hydrazide, and relatively resistant to $p$-aminosalicylic acid. A few strains were positive for niacin production. Biochemical, drug-susceptibility and biological tests were performed by standard procedures (Wayne \& Kubica, 1986).

RFLP and spoligotyping techniques. The RFLP technique using IS6110 and mtp40 as genetic markers was described previously (Romano et al., 1995). Spoligotyping was performed according to Kamerbeek et al. (1997). Clustering analysis using UPGMA and the Dice coefficient of spoligotypes was performed with the aid of the computer program 
Table 1. Origin of the mycobacteria isolated from seals and their spoligotypes and IS6110 RFLP types

\begin{tabular}{|c|c|c|c|c|c|}
\hline $\begin{array}{l}\text { Clinical } \\
\text { case }\end{array}$ & Host species & Origin & $\begin{array}{l}\text { Date of } \\
\text { isolation }\end{array}$ & Spoligotype & $\begin{array}{l}\text { IS6110 RFLP } \\
\text { pattern }\end{array}$ \\
\hline $1 *$ & Otaria flavescens & Uruguay & 1987 & 1 & $\mathrm{~B}$ \\
\hline 2 & Arctocephalus australis & Argentina & 1991 & 1 & B \\
\hline 3 & Arctocephalus australis & Argentina & 1992 & 1 & $\mathrm{~B}$ \\
\hline 4 & Arctocephalus australis & Argentina & 1992 & 1 & $\mathrm{~A}$ \\
\hline 5 & Arctocephalus australis & Argentina & 1992 & 1 & $\mathrm{C}$ \\
\hline 6 & Arctocephalus australis & Argentina & 1995 & 1 & $\mathrm{D}$ \\
\hline 7 & Arctocephalus australis & Argentina & 1996 & 1 & $\mathrm{E}$ \\
\hline 8 & Arctocephalus tropicalis & Argentina & 1996 & 1 & $\mathrm{~A}$ \\
\hline 9 & Arctocephalus australis & Argentina & 1996 & 1 & $\mathrm{~B}$ \\
\hline 10 & Arctocephalus australis & Argentina & 1996 & 2 & $\mathrm{~F}$ \\
\hline
\end{tabular}

* This case was from an outbreak of TB in captive sea lions.

GelCompar, version 2.1 (Applied Maths, Kortrijk, Belgium). The spoligotypes found in the mycobacteria isolated from seals were compared with the spoligotypes found in over 609 M. bovis isolates that originated from different sources (human, cattle, cat, goat, llama, buffalo and deer) and from different countries in Latin America and Europe.

Production of MPB70 antigen. To prepare mycobacterial culture supernatant and sonic extracts, cultures were centrifuged for $30 \mathrm{~min}$ at $10000 \mathrm{~g}$. For cell extracts, bacteria were resuspended in distilled water and sonicated for 10 cycles of $30 \mathrm{~s}$ followed by a $30 \mathrm{~s}$ interval. The culture supernatant was precipitated with trichloroacetic acid $(10 \%)$ and resuspended in loading buffer ( $2 \%$ SDS, $0 \cdot 125 \mathrm{M}$ Tris $/ \mathrm{HCl} \mathrm{pH} \mathrm{6.8,} 1 \%$ 2mercaptoethanol, $0.02 \%$ bromophenol blue, $10 \%$ glycerol).

Proteins $(50 \mu \mathrm{g})$ were analysed by electrophoresis in $12 \%$ polyacrylamide-SDS gels and electrotransferred onto a nitrocellulose sheet by the semidry method. Transfer yield was visualized by transient staining with Ponceau Rouge. The membranes were incubated with monoclonal antibody 4C3/17 against MPB70 (CSL Laboratories, Victoria, Australia) overnight at $4{ }^{\circ} \mathrm{C}$ and with an alkaline-phosphataseconjugated goat-antimouse antiserum (Sigma) for $2 \mathrm{~h}$ at $37^{\circ} \mathrm{C}$.

\section{PCR and DNA sequencing}

pncA. The $p n c A$ gene was amplified by PCR, using primers PNCA-1 and PNCA-2. To determine the sequence of $p n c A$ (GenBank accession no. U59967) from various strains of mycobacteria isolated from seals, primer PNCA-1 (5'-ATGCGGGCGTTGATCATCGTC-3'), corresponding to bp 1-21 of the M. tuberculosis pncA gene, and primer PNCA-2 (5'-TCAGGAGCTGCAAACCAA-3'), corresponding to bp 561-544 of the same gene (Scorpio \& Zhang, 1996) were used. PCR was performed using PCR buffer composed of $10 \mathrm{mM}$ Tris/HCl, $\mathrm{pH} 8 \cdot 8 ; 50 \mathrm{mM} \mathrm{KCl} ; 1.5 \mathrm{mM} \mathrm{MgCl}_{2} ; 0 \cdot 125 \mu \mathrm{M}$ of the above-mentioned primers; $0.125 \mathrm{mM}$ dNTPs; 1.25 units Taq DNA polymerase (Advanced Biotechnologies); and 10-100 ng DNA. PCR amplification was performed in a Perkin-Elmer Cetus DNA thermal cycler, set for $3 \mathrm{~min}$ at $94{ }^{\circ} \mathrm{C}$, followed by 40 cycles at $94{ }^{\circ} \mathrm{C}$ for $1 \mathrm{~min}, 62^{\circ} \mathrm{C}$ for 1 $\mathrm{min}$, and $72{ }^{\circ} \mathrm{C}$ for $1 \mathrm{~min}$. The pncA sequences from different mycobacterial strains were determined by PCR direct sequencing, using a Thermo Sequenase labelled primer cycle sequencing kit (Amersham) with fluorescent 5' Cy 5-labelled PNCA-1 and PNCA-2 primers, in an automatic DNA sequencer (ALFexpress, Pharmacia).
katG. Detection of point mutations in the catalase-peroxidase gene (katG) (GenBank accession no. X68081) was performed as described by Uhl et al. (1996).

gyrA. To determine the mutations of the quinolone-resistancedetermining region of the gene gyrA (GenBank accession no. L27512) from M. tuberculosis strains, a region of 320 bp was amplified and sequenced. The forward primer GyrA1 (5'CAGCTACATCGACTATGCGA-3'), corresponding to bp 2383-2402 of gyrA, and the reverse primer GyrA2 $\left(5^{\prime}-\right.$ GGGCTTCGGTGTACCTCAT-3'), corresponding to bp 2684-2702 of this gene, were used. PCR and sequencing was performed as described above for $p n c A$ except that an annealing at $60{ }^{\circ} \mathrm{C}$ for $1 \mathrm{~min}$ was used in the PCR, and GyrA1 and GyrA2 were used as sequencing primers.

16S rRNA. A $1030 \mathrm{bp}$ fragment of $16 \mathrm{~S}$ rRNA from $M$. tuberculosis (GenBank accession no. X52917) was amplified using $50 \mathrm{pmol}$ each of primers 285 (5'-GAGAGTTTGATCCTGGCTCAG-3'), corresponding to bp 9-30 of the E. coli $16 \mathrm{~S}$ rRNA, and 264 (5'-TGCACACAGGCCACAAGGGA$\left.3^{\prime}\right)$, corresponding to bp 1027-1046 of the E. coli $16 \mathrm{~S}$ rRNA (GenBank accession no. U59967) per $50 \mu \mathrm{l}$ of reaction, as described by Kirschner et al.. (1993). The cycling parametres were $95^{\circ} \mathrm{C}$ for $5 \mathrm{~min}$, followed by 40 cycles of $95^{\circ} \mathrm{C}$ for $1 \mathrm{~min}$, $68^{\circ} \mathrm{C}$ for $1 \mathrm{~min}$ and $72^{\circ} \mathrm{C}$ for $1 \mathrm{~min}$. The reaction was performed in a Perkin-Elmer Cetus DNA thermal cycler.

The $16 \mathrm{~S}$ rRNA sequence was determined by PCR direct sequencing using a Thermo Sequenase labelled primer cycle sequencing kit (Amersham), with the fluorescent $5^{\prime}$ Cy 5labelled 244 (5'-CCCACTGCTGCCTCCCGTAG-3') primer corresponding to bp 341-361 of the E. coli $16 \mathrm{~S}$ rRNA, in an automatic DNA sequencer (ALFexpress, Pharmacia).

\section{PCR-restriction analysis}

hsp65. Specific amplification of a fragment of 439 bp of $h s p 65$ (GenBank accession no. M15467) from each strain, and digestion by BstEII and HaeIII of the amplified fragments, were performed according to the procedure described by Telenti et al. (1993). Following digestion, $10 \mu \mathrm{l}$ of the mixture was loaded onto a $4 \%$ agarose gel. The $10 \mathrm{bp}$ DNA ladder (Gibco-BRL) was used as the molecular marker.

oxyR. A 548 bp segment of the oxyR pseudogene of the $M$. tuberculosis complex (GenBank accession no. U16243) was amplified with the forward primer 5'-GGTGATATATCAC- 
ACCATA-3' and the reverse primer 5'-CTATGCGATCAGGCGTACTTG-3', and restriction fragment length polymorphism of the amplified product with restriction endonuclease $A l u \mathrm{I}$ was analysed as described by Sreevatsan et al. (1996), to differentiate M. bovis from other complex members. PCR was performed as described above for $p n c A$ except that the cycling conditions used were 30 cycles at $96^{\circ} \mathrm{C}$ for $1 \mathrm{~min}$, $55^{\circ} \mathrm{C}$ for $1 \mathrm{~min}$ and $72^{\circ} \mathrm{C}$ for $1 \mathrm{~min}$.

\section{RESULTS}

\section{Bacteriology and biological assays}

All the mycobacteria isolated from seals grew in Stonebrink medium. None of the Argentine strains grew in Löwenstein-Jensen medium, while the strain from Uruguay grew very slowly in that medium.

Experimental inoculation of guinea pigs with the mycobacteria isolated from seals produced significant and generalized lesions, and the intradermal tuberculin test with M. bovis purified protein derivative (PPD: $50 \mathrm{IU})$, of the experimentally inoculated guinea pigs gave a strong positive reaction. There was an increase of $6 \mathrm{~mm}$ or more in skinfold thickness, and these reactions were 6-16 times greater than with M. avium PPD.

\section{Genetic characterization}

Mycobacterium species can be differentiated by amplification of a fragment of the $h s p 65$ gene followed by restriction enzyme analysis (Telenti et al., 1993), and by sequencing of a region of the $16 \mathrm{~S}$ rRNA (Kirschner et al., 1993), because these genes exhibit some internal polymorphism within these regions. Mycobacteria from different seal isolates had DNA fragment sizes generated

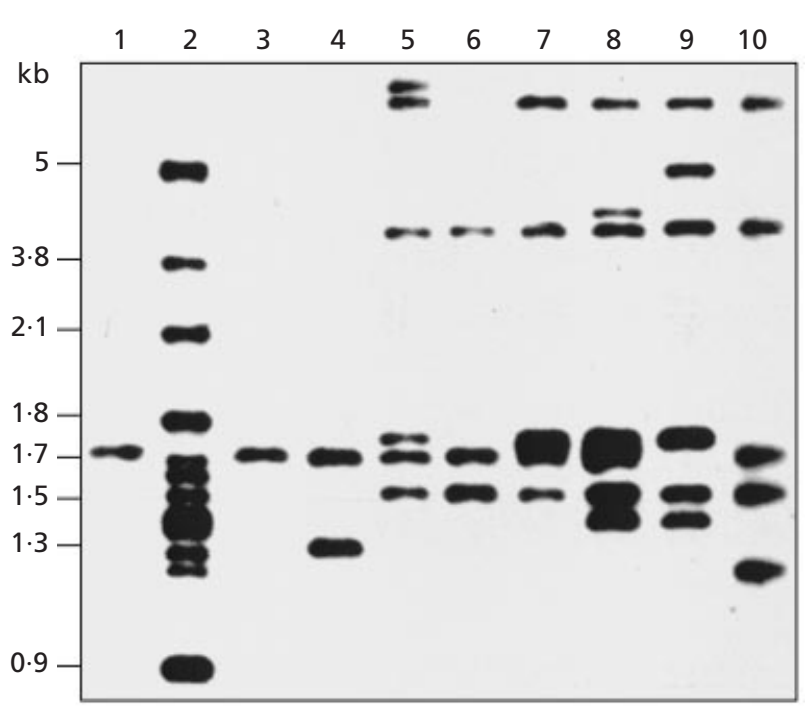

Fig. 1. RFLPs of $M$. tuberculosis complex strains. DNAs were digested with Pvull, and probed with the right arm of IS6110. Lanes: 1, M. bovis isolate; 2, M. tuberculosis H37Rv; 3, M. bovis AN5; 4, BCG Brazil; 5, mycobacteria isolated from wild seal type C; 6, mycobacteria isolated from wild seal type $A ; 7$, mycobacteria isolated from wild seal type $B ; 8$, mycobacteria isolated from wild seal type $D ; 9$, mycobacteria isolated from wild seal type $\mathrm{F} ; 10$, mycobacteria isolated from wild seal type E. The fragment sizes of $M$. tuberculosis H37Rv after digestion with Pvull and hybridization with IS6110 are indicated on the left.

after amplification of $h s p 65$ followed by digestion with BstEII and HaeIII identical to the organisms belonging to the M. tuberculosis complex (data not shown). The

Table 2. Comparison of genetic and antigenic characteristics between mycobacteria isolated from seals, $M$. tuberculosis and $M$. bovis

\begin{tabular}{|c|c|c|c|}
\hline Gene/antigen & M. tuberculosis & M. bovis & $\begin{array}{l}\text { Mycobacteria } \\
\text { isolated from seals }\end{array}$ \\
\hline $16 \mathrm{~S}$ rRNA & M. tuberculosis complex & M. tuberculosis complex & $\begin{array}{l}\text { M. tuberculosis } \\
\text { complex }\end{array}$ \\
\hline hsp65 (PRA*) & M. tuberculosis complex & M. tuberculosis complex & $\begin{array}{l}\text { M. tuberculosis } \\
\text { complex }\end{array}$ \\
\hline IS6110 element $†$ & + (multi-copy) & + (one copy) & $+($ multi-copy $)$ \\
\hline$m t p 40+$ & + & - & + \\
\hline Detection of MPB70 antigen & - & + & - \\
\hline kat $G$ codon 463 & $\begin{array}{l}\text { CTG (Leu) (group 1) } \\
\text { or CGG (Arg) (groups } 2 \text { and } 3 \text { ) }\end{array}$ & CTG (Leu) & CTG (Leu) \\
\hline gyrA codon 95 & $\begin{array}{l}\text { ACC (Thr) (groups } 1 \text { and } 2) \\
\text { or AGC (Ser) (group 3) }\end{array}$ & ACC (Thr) & ACC (Thr) \\
\hline pncA nt 169 mutation & CAC (His) & GAC (Asp) & CAC (His) \\
\hline oxyR nt 285 mutation & Guanine & Adenine & Guanine \\
\hline
\end{tabular}




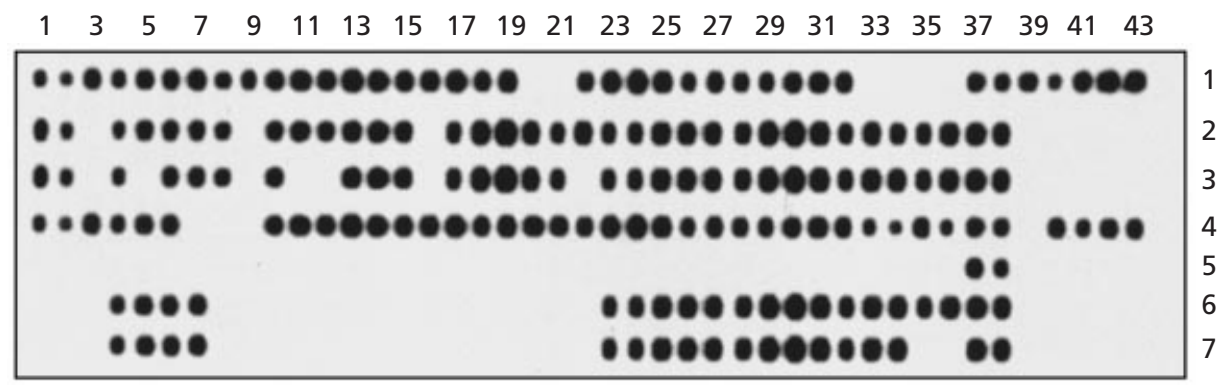

Fig. 2. Spoligotypes of $M$. tuberculosis complex strains. Rows: $1, M$. tuberculosis H37Rv; $2, B C G ; 3, M$. bovis AN5; 4 , $M$. africanum; 5 , M. microti; 6 , mycobacteria isolated from a seal with spoligotype $1 ; 7$, mycobacteria isolated from a seal with spoligotype 2 (case 10). The numbers at the top of the figure correspond to the 43 spacer oligonucleotides numbered as described by Kamerbeek et al. (1997).

sequence of the amplified $16 \mathrm{~S}$ rRNA gene of the different mycobacteria isolated from seals was identical to the sequence of the members of the M. tuberculosis complex (data not shown). According to their $16 \mathrm{~S}$ rRNA gene sequence and the PCR-restriction characteristics of the hsp65 gene, the seal isolates were identified as belonging to the M. tuberculosis complex (Table 2). The IS6110 element and DR region, both sequences characteristic of the M. tuberculosis complex, were found in the DNA of the mycobacteria isolated from seals (Fig. 1 and 2, Tables 1 and 2). These mycobacteria had spoligotypes different from those in M. tuberculosis, M. africanum, M. microti and M. bovis AN5 (Fig. 2). All the seal isolates lacked the spacers 39-43. The absence of these spacers is characteristic of M. bovis isolates. Clustering analysis using UPGMA and the Dice coefficient of spoligotypes was performed to compare the spoligotypes found in the mycobacteria isolated from seals with the spoligotypes of over $609 \mathrm{M}$. bovis isolates from different countries in Latin America and Europe, and with the spoligotypes of BCG and M. bovis AN5. The analysis of these spoligotypes showed that the spoligotypes of the mycobacteria isolated from seals were exclusive to these isolates (Fig. 3).

Some of the mycobacteria isolated from seals (clinical cases 2, 4, 5, 6, 7 and 10 from Table 1) were tested for polymorphisms in the oxyR and $p n c A$ genes; they showed M. tuberculosis-specific polymorphism in both genes (Table 2). In addition, these mycobacteria had the same sequence polymorphisms of gyr $A$ and $k a t G$ as do group $1 M$. tuberculosis, and M. bovis (Table 2).

The MPB70 antigen, which is always detected in $M$. bovis, was not detected in the mycobacteria from seals (Table 2).

\section{Epidemiological implications}

Spoligotyping and IS6110-RFLP techniques were used to study the epidemiology of the TB in seals. Six IS6110RFLP types were found among the 10 seal isolates (Table 1). These isolates contained three to seven copies of IS6110 (Fig. 1). The IS6110-RFLP types were arbitrarily designated as A-F. IS6110-RFLP type A contained three copies of this element (Fig. 1), and was found in mycobacteria isolated from two seals (Table 1). One of the animals belonged to the species Arctocephalus australis and was found stranded on the Argentine coast in 1992 (Table 1, case 4); the second mycobacterial isolate was obtained in 1996 from an Arctocephalus tropicalis individual (Table 1, case 8). IS6110-RFLP type B contained five copies of IS6110 (Fig. 1 ), and was found in mycobacteria isolated from four seals (Table 1): one Otaria flavescens individual, involved in an outbreak of TB in 1987 at the Montevideo Zoo, Uruguay (Table 1, case 1), and three wild seals of the species A. australis found on the Argentine coast, in 1991, 1992 and 1996 (Table 1, cases 2, 3 and 9, respectively). The remaining four RFLP types $(\mathrm{C}, \mathrm{D}, \mathrm{E}$ and $F$ ) were found in mycobacteria isolated from four different animals (Table 1, cases 5, 6, 7 and 10, respectively).

Although there were six different IS6110 fingerprint patterns, they shared many of their IS6110-containing restriction fragments (Fig. 1). Mycobacteria isolated from nine animals had an identical spoligotype. Only one isolate showed a minor difference: it had two missing spacers in its spoligotype (Fig. 2; Table 1, case 10). This individual corresponded to the last isolate (September, 1996), which also showed a unique IS6110 RFLP pattern (F) (Fig. 1; Table 1, case 10).

\section{DISCUSSION}

Based on the $16 \mathrm{~S}$ rRNA and $h s p 65$ nucleotide sequences, as well as on the presence of the insertion sequence IS6110 and DR region, we have confirmed that the mycobacteria isolated from seals belong to the $M$. tuberculosis complex. These bacteria had some of the genetic characteristics of $M$. bovis, and other genetic and antigenic characteristics identical to $M$. tuberculosis. Several molecular strategies were used to characterize the mycobacterial isolates from seals. Spoligotypes found in these isolates were exclusive to isolates from seals, and lacked spacers 39-43, as does M. bovis. In contrast, the restriction analysis of $o x y R$, and the nucleotide sequence of $p n c A$, showed polymorphisms characteristic of M. tuberculosis. These results indicated that the mycobacteria isolated from seals belong to a 


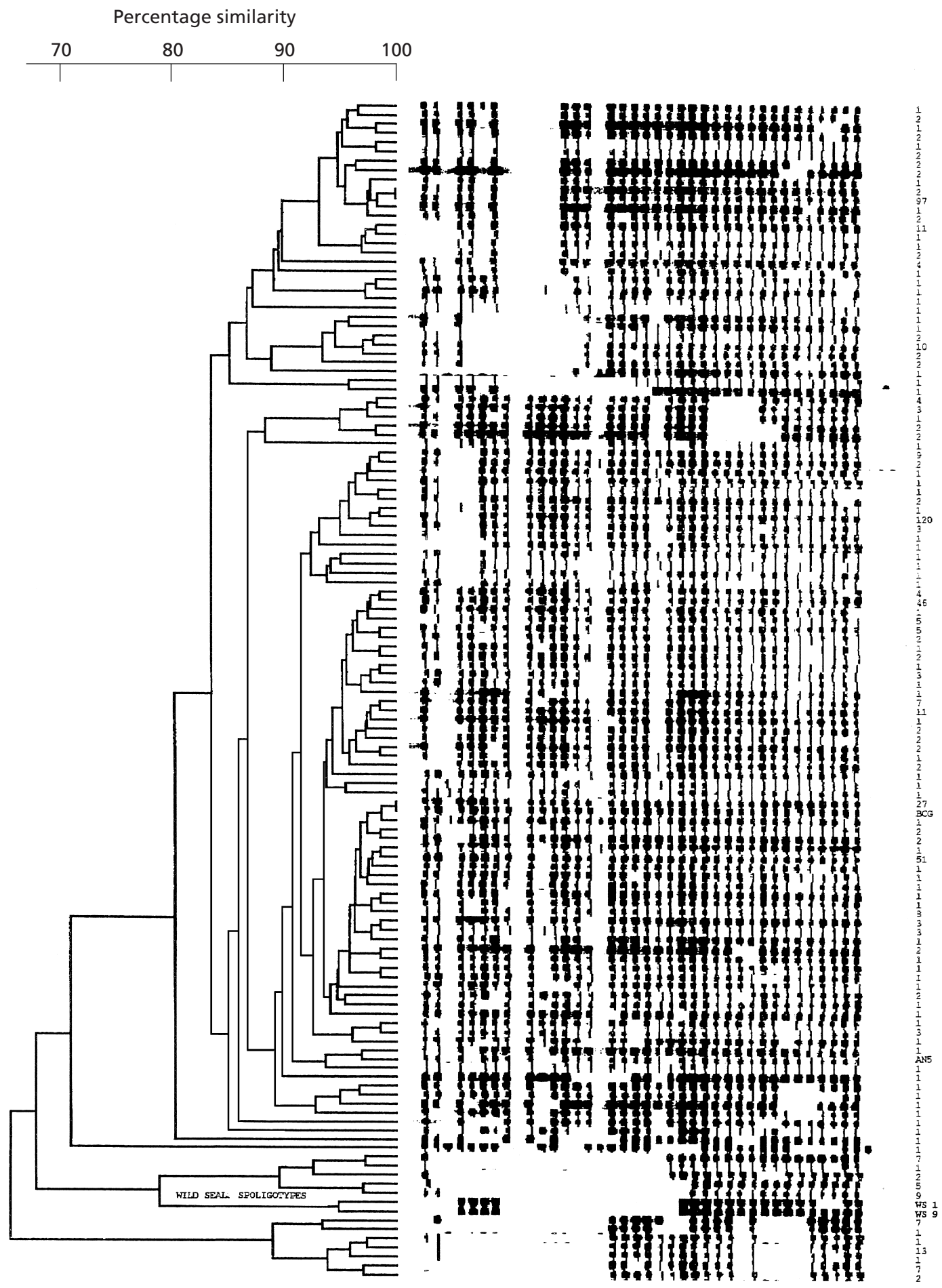

Fig. 3. Dendogram with 125 spoligotypes identified among $609 \mathrm{M}$. bovis isolates studied of human and animal origin in the authors' laboratories in Spain and Argentina and the spoligotypes from mycobacteria isolated from seals. The spoligotypes of BCG and $M$. bovis AN5 were also included. The numbers on the right correspond to the number of isolates for each spoligotype. Seal spoligotypes are indicated in the dendogram, and are also indicated on the right with the letters WS.

unique genotypic group inside the $M$. tuberculosis complex. In addition, the mycobacteria isolated from seals, as does M. bovis, grew better in Stonebrink than in Löwenstein-Jensen medium and their spoligotypes lacked the spacers 39-43 (Fig. 2); and like M. tuberculosis, they did not produce detectable amounts of MPB70 antigen (Table 2 ) and contained $m t p 40$ (Romano et al., 1995). Based on these results, the mycobacteria 
isolated from seals can be considered to share genotypic characteristics with different members the M. tuberculosis complex.

In the present study, the spoligotypes of the mycobacteria isolated from seals were identical; only the most recent isolate showed a minor difference in its spoligotype. However, the isolates with the same spoligotype could be differentiated by RFLP analysis with the IS6110 probe. Thus the IS6110 element was more useful than spoligotyping to assess the epidemiological relationship between these mycobacteria. In a previous study, mycobacteria isolated from seals were also typed by RFLP analysis with DR and polymorphic GC-rich repetitive sequence (PGRS) probes. All strains showed the same DR and PGRS patterns, except for one strain which showed a minor difference with the DR probe (Romano et al., 1995), suggesting an epidemiological relationship between these isolates.

The similarities in IS6110-associated RFLPs among mycobacteria isolated from seals suggest that they may have recently diverged from a common ancestor. It is not possible to calculate exactly the time elapsed since the divergence from this putative common ancestor. Another group of strains, which share the majority of their IS6110-containing restriction fragments, are those M. tuberculosis strains which have been circulating in the Republic of China (Beijing family); in this case the authors proposed that they have evolved from recent clonal expansion that began less than a century ago (van Soolingen et al., 1995).

The cases of TB reported in this study were in animals that came from the rookeries situated on the Argentine and Uruguayan coasts. Most of the individuals found stranded on the Argentine coast were physiologically depressed, with a higher percentage of diverse illnesses than is generally seen in animals from natural colonies. This situation could contribute to the active transmission of the $\mathrm{TB}$ infection and the illness may be endemic among these animals. The results of van Soolingen et al. (1991) indicated that IS6110 patterns from M. tuberculosis strains from regions where TB is endemic are more related to each other than isolates from countries where the transmission rate is slow. Thus, similar IS6110 types between mycobacterial isolates from seals are a sign of an active transmission of TB between these animals.

IS6110-RFLP type B was found in a mycobacterial isolate, which caused tuberculosis in a colony of captive seals of the species O. flavescens, at Montevideo Zoo (Uruguay) (Castro Ramos et al., 1998). These captive seals were collected from wild colonies in Uruguay and at least one of them may have been ill at the time of the capture. This same RFLP type was found in mycobacterial isolates from TB cases in wild seals of the species $A$. australis, found stranded on the Argentine coast. This is probably due to the fact that seals of these two species inhabit the same islands in Uruguay. IS6110RFLP type A was found in wild seals of the species $A$. australis and A. tropicalis, stranded on the Argentine coast. The presence of the latter species is incidental on this coast, because it comes from subantarctic islands near South Africa. These 'wandering' specimens are swept north by the Benguela current, reach the equatorial current in the direction of South America, and then arrive at the Argentine coast pushed by the Brazil current (Rodríguez et al., 1995).

Cases of TB in other species of marine mammals have also been described in Australia and New Zealand (Neophoca cinerea, Arctocephalus forsteri and A. pusillus doriferus) (Cousins et al., 1990, 1993; Forshaw \& Phelps, 1991; Thompson et al., 1993), where these mycobacteria infected a seal trainer (Cousins et al., 1993; Thompson et al., 1993). The restriction endonuclease analysis and RFLP patterns of these seal isolates were different from those of other members of the $M$. tuberculosis complex, and the protein MPB70, present in $M$. bovis, was not detected in these seal isolates (Cousins et al., 1993). Comparisons between Australian and Argentinian isolates would be necessary to determine whether there is a single or multiple origin of this animal disease.

The importance of the results presented here is that they indicate that there are new mycobacteria in the $M$. tuberculosis complex, which cause $\mathrm{TB}$ in marine mammals and appear to be specific to these animals, and which are actively transmitted within the animal colonies. It will be necessary to study the prevalence of this disease in the seal colonies of Uruguay and Argentina, in addition to controlling the human population that has contact with these animals.

\section{ACKNOWLEDGEMENTS}

This study was supported by a grant from Fondo Mixto de Cooperación Hispano Argentino and the Ministry of Health, Spain (Fondo de Investigaciones Sanitarias) FIS 97-0042.

We are grateful to Haydee Gil for her excellent technical assistance, and to Mariana del Vas and Laura Boschiroli for their critical observations.

C.M., A.C. and M.I.R. are fellows of the RELACTB (Red Latinoamericana del Caribe de Tuberculosis). A.C. and M.I.R. are fellows of the National Research Council of Argentina (CONICET).

\section{REFERENCES}

Aranaz, A., Liébana, E., Mateos, A. \& 8 other authors (1996). Spacer oligonucleotide typing of Mycobacterium bovis strains from cattle and other animals: a tool for studying epidemiology of tuberculosis. J Clin Microbiol 34, 2734-2740.

Bernardelli, A., Loureiro, J., Costa, E., Cataldi, A., Bastida, R. \& Michelis, H. (1993). Tuberculosis in fur seals and sea lions of the south-western Atlantic coast. Meeting of IUATLD, Paris.

Bernardelli, A., Bastida, R., Loureiro, J., Michelis, H., Romano, M. I., Cataldi, A. \& Costa, E. (1996). Tuberculosis in sea lions and fur seals from the south-western. Rev Sci Tech Off Int Epiz 15, 985-1005.

Blázquez, J., Espinosa de Los Monteros, L. E., Samper, S., Martín, C., Guerrero, A., Cobo, J., van Embden, J., Baquero, F. \& GómezMampaso, E. (1997). Genetic characterization of multidrug- 
resitant Mycobacterium bovis strains from a hospital outbreak involving human immunodeficiency virus-positive patients. J Clin Microbiol 35, 1390-1393.

Castro Ramos, M., Ayala, M., Errico F. \& Silvera, F. V. (1998) Primeros aislamientos de Mycobacterium bovis en Pinnipedos Otaria byronia (lobo marino común) en Uruguay. Rev Med Vet 79, 197-200.

Collins, C. H., Grange, J. M. \& Yates, M. D. (1985). Tuberculosis Bacteriology, pp. 59-66. London: Butterworths.

Cousins, D. V., Francis, B. R., Gow, B. L., Collins, D. M., McGlashan, C. H., Gregory, A. \& MacKenzie, R. M. (1990). Tuberculosis in captive seals: bacteriological studies on an isolate belonging to the Mycobacterium tuberculosis complex. Res Vet Sci 48, 196-200.

Cousins, D. V., Williams, S. N., Reuter, R., Forshaw, D., Chadwick, B., Coughran, D., Collins, P. \& Gales, N. (1993). Tuberculosis in wild seals and characterization of the seal bacillus. Aust Vet J 70, 92-97.

Cousins, D., Williams, S., Liébana, E., Aranaz, A., Bunschoten, A., van Embden, J. \& Ellis, T. (1998). Evaluation of four DNA typing techniques in epidemiological investigations of bovine tuberculosis. J Clin Microbiol 36, 168-178.

Del Portillo, P., Murillo, L. A. \& Patarroyo, M. E. (1991). Amplification of a species-specific DNA fragment of Mycobacterium tuberculosis and its possible use in diagnosis. J Clin Microbiol 29, 2163-2168.

Deretic, V., Song, J. \& Pagán-Ramos, E. (1997). Loss of $o x y R$ in Mycobacterium tuberculosis. Trends Microbiol 5, 367-372.

Forshaw, D. \& Phelps, G. R. (1991). Tuberculosis in a captive colony of pinnipeds. J Wildl Dis 27, 288-295.

Goguet de la Salmonière, Y. O., Minh Li, H., Torrea, G., Bunschoten, A., van Embden, J. \& Gicquel B. (1997). Evaluation of spoligotyping in a study of the transmission of Mycobacterium tuberculosis. J Clin Microbiol 35, 2210-2214.

Hermans, P. W. M., van Soolingen, D., Bik, E. M., de Haas, P. E. W., Dale, J. W. \& van Embden, J. D. A. (1991). Insertion element IS987 from Mycobacterium bovis BCG is located in a hot-spot integration region for insertion elements in $\mathrm{Myco-}$ bacterium tuberculosis complex strains. Infect Immun $\mathbf{5 9}$, 2695-2705.

Harboe, M. \& Nagai, S. (1984). MPB70, a unique antigen of Mycobacterium bovis BCG. Am Rev Resp Dis 129, 444-452.

Hermans, P. W. M., Martín, C., McAdam, R., Shinnick, T. M. \& Small, P. M. (1992). Strain identification of Mycobacterium tuberculosis by DNA fingerprinting: recomendations for a standardized methodology. J Clin Microbiol 31, 406-409.

Kamerbeek, J., Schouls, L., Kolk, A. \& 8 other authors (1997). Simultaneous detection and strain differentiation of $\mathrm{Myco-}$ bacterium tuberculosis for diagnosis and epidemiology. J Clin Microbiol 35, 907-914.

Kirschner, P., Springer, B., Meier, A., Wrede, A., Kiekenbeck, M., Bange, F. C., Vogel, U \& Böttger E. C. (1993). Genotypic identification of mycobacteria by nucleic acid sequence determination: report of a 2-year experience in a clinical laboratory. $J$ Clin Microbiol 31, 2882-2889.

Rodríguez, D., Bastida, R., Moron, S. \& Loureiro, J. (1995). Registros de lobos marinos subantárticos (Arctocephalus tropicalis) en Argentina. VI Congreso Latinoamericano de Ciencias del Mar, p. 170.

Romano, M. I., Alito, A., Bigi, F., Fisanotti, J. C. \& Cataldi, A. (1995). Genetic characterization of mycobacteria from South American wild seals. Vet Microbiol 47, 89-98.
Romano, M. I., Alito, M. I., Fisanotti, J. C., Bigi, F., Kantor, I., Cicuta, M. E. \& Cataldi, A. (1996). Comparison of different genetic markers for molecular epidemiology of bovine tuberculosis. Vet Microbiol 50, 59-71.

Samper, S., Martín, C., Pinedo, A., Rivero, A., Blázquez, J., Baquero, F., van Soolingen, D. \& van Embden, J. D. A. (1997). Transmission between HIV-infected patients of multidrug-resistant tuberculosis caused by Mycobacterium bovis. AIDS 11, 1237-1242.

Scorpio, A. \& Zhang Y. (1996). Mutations in $p n c A$, a gene encoding pyrazinamidase/nicotinamidase, cause resistance to antituberculous drug pyrazinamide in tubercle bacillus. Nat Med 2, 662-667.

van Soolingen, D., Hermans, P. W. M., de Haas, P. E. W., Soll, D. R. \& van Embden, J. D. A. (1991). Occurrence and stability of insertion sequences in Mycobacterium tuberculosis complex strains: evaluation of an insertion sequence-dependent DNA polymorphism as a tool in the epidemiology of tuberculosis. J Clin Microbiol 29, 2578-2586.

van Soolingen, D., de Haas, P. E. W., Hermans, P. W. M., Groenen, P. M. A. \& van Embden, J. D. A. (1993). Comparison of various repetitive elements as genetic markers for strain differentiation and epidemiology of Mycobacterium tuberculosis. J Clin Microbiol 29, 2578-2586.

van Soolingen, D., Lishi, Q., de Haas, P. E. W. \& 7 other authors (1995). Predominance of a single genotype of Mycobacterium tuberculosis in countries of East Asia. J Clin Microbiol 33, 3234-3238.

Sreevatsan, S., Escalante, P., Pan, X. \& 11 other authors (1996). Identification of a polymorphic nucleotide in oxyR specific for Mycobacterium bovis. J Clin Microbiol 34, 2007-2010.

Sreevatsan, S., Pan, X., Stockbauer, K. E., Connell, N. D., Kreiswirth, B. N., Whittam, T. S. \& Musser, J. M. (1997). Restricted structural gene polymorphism in the Mycobacterium tuberculosis complex indicates evolutionarily recent global dissemination. Proc Natl Acad Sci USA 94, 9869-9874.

Telenti, A., Marchesi, F., Baltz, M., Bally, F., Bottger, E. C. \& Bodmer, T. (1993). Rapid identification of mycobacteria to the species level by polymerase chain reaction and restriction enzyme analysis. J Clin Microbiol 31, 175-178.

Thompson, P. Y., Cousins, D. V., Gow, B. L., Collins, D. M., William-Son, B. H. \& Dagnia H. T. (1993). Seals, seal trainers and mycobacterial infection. Ann Rev Respir Dis 147, 164-167.

Uhl, J. R., Ssandhu, G. S., Kline, B. C. \& Cockerill F. R. (1996). PCRRFLP detection of point mutations in the catalase-peroxidase gene (kat $\mathrm{G}$ ) of Mycobacterium tuberculosis associated with isoniazid resistance. In PCR Protocols for Emerging Infectious Diseases, pp. 144-149. Edited by David H. Persing. Washington, DC: American Society for Microbiology.

Wayne, L. G. \& Kubica, G. P. (1986). Genus Mycobacterium. In Bergey's Manual of Systematic Bacteriology, vol. 2, pp. 1435-1457. Edited by P. H. A. Sneath and others. Baltimore: Williams \& Wilkins.

Weil, A., Plikaytis, B. B., Butler, W. R., Woodley, C. L. \& Shinnick, T. M. (1996). The $m t p 40$ gene is not present in all strains of Mycobacterium tuberculosis. J Clin Microbiol 34, 2309-2311.

Zumárraga, M. J., Martin, C., Samper, S. \& 10 other authors (1999). Usefulness of spoligotyping in the molecular epidemiology of Mycobacterium bovis-related infections in South American countries. J Clin Microbiol 37, 296-303.

Received 13 January 1999; revised 10 May 1999; accepted 12 May 1999. 